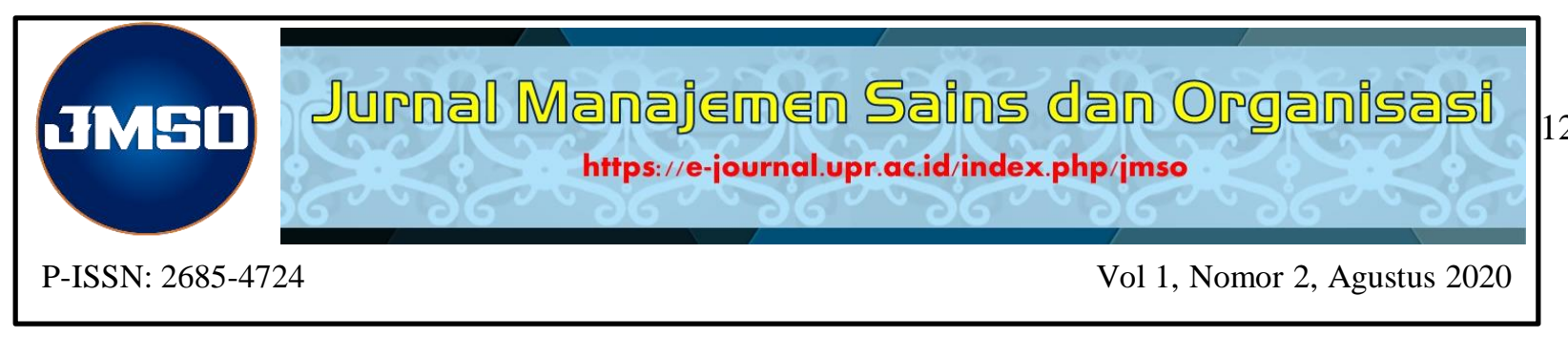

\title{
Pengaruh leverage dan profitabilitas terhadap nilai perusahaan dengan kebijakan dividen sebagai variabel intervensi pada indeks BEI 30 yang tercantum di bursa efek indonesia
}

\author{
Puji Setiawati ${ }^{1)}$ \\ Fakultas Ekonomi dan Bisnis \\ Universitas Palangka Raya, Indonesia \\ Email: pujisetiawati0910@gmail.com
}

\begin{abstract}
Abstrak
Tujuan - Penelitian ini bertujuan untuk memberikan penjelasan secara empiris tentang pengaruh leverage dan profitabilitas terhadap nilai perusahaan dengan kebijakan dividen sebagai variabel intervening pada indeks IDX30 yang terdaftar di Bursa Efek Indonesia.

Desain/Metodelogi/Pendekatan - Metode penelitian yang digunakan deskriptif-kuantitatif. Sumber data diperoleh dari akun resmi www.idx.co.id terhadap 30 perusahaan yang tergabung pada indeks IDX30 yang terdaftar di Bursa Efek Indonesia. Sampel diambil 6 perusahaan dengan menggunakan metode purposive sampling. Data yang terkumpul dianalisis dengan menggunakan alat analisis SmartPLS 3.0

Temuan - Hasil penelitian menunjukkan bahwa leverage tidak berpengaruh signifikan positif terhadap nilai perusahaan, profitabilitas berpengaruh signifikan positif terhadap nilai perusahaan, leverage berpengaruh signifikan negatif terhadap kebijakan dividen, profitabilitas berpengaruh signifikan positif terhadap kebijakan dividen, kebijakan dividen berpengaruh signifikan positif terhadap nilai perusahaan, leverage tidak berpengaruh signifikan negatif terhadap nilai perusahaan melalui kebijakan dividen dan profitabilitas tidak berpengaruh signifikan positif terhadap nilai melalui kebijakan dividen.
\end{abstract}

Kata kunci: leverage, profitabilitas, kebijakan dividend dan nilai perusahaan

\section{The effect of leverage and profitability on firm value with dividend policy as an intervention variable on the BEI 30 index listed on the Indonesian stock exchange}

\begin{abstract}
Purpose - This study aims to provide an empirical explanation of the effect of leverage and profitability on firm value with dividend policy as an intervening variable on the IDX30 index listed on the Indonesia Stock Exchange.

Design / Methodology / Approach - The research method used is descriptive-quantitative. Data sources were obtained from the official www.idx.co.id account of 30 companies that are members of the IDX30 index which are listed on the Indonesia Stock Exchange. The sample was taken from 6 companies using purposive sampling method. The collected data were analyzed using the SmartPLS 3.0 analysis tool Findings - The results showed that leverage has no significant positive effect on firm value, profitability has a significant positive effect on firm value, leverage has a significant negative effect on dividend policy, profitability has a significant positive effect on dividend policy, dividend policy has a significant positive effect on firm value, leverage does not has a significant negative effect on firm value through dividend policy and profitability does not have a significant positive effect on value through dividend policy.
\end{abstract}

Keywords: leverage, profitability, dividend policy and firm value

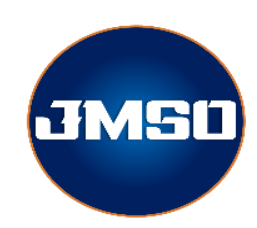

Jurnal Manajemen Sains dan Organisasi Vol 1, No 2, 2020 pp. 124 - 138 FEB UPR Publishing $2685-4724$
Puji Setiawati, Solikah Nurwati. Published in the Jurnal Manajemen sains dan Organsasi. Published by FEB UPR Publishing Limited. This article is published under the Creative Commons Attribution (CC BY 4.0) licence. Anyone may reproduce, distribute, translate and create derivative works of this article (for both commercial and noncommercial purposes), subject to full attribution to the original publication and authors. 


\section{Pendahuluan}

Didirikannya sebuah perusahaan tentunya memiliki sebuah tujuan yang jelas. Tujuan pertama yaitu untuk mencapai keuntungan maksimal atau laba yang sebesarbesarnya. Kedua yaitu untuk mensejahterakan manajer dan investor. Terakhir yaitu untuk memaksimalkan nilai perusahaan yang tercermin pada harga saham perusahaan. Sebenarnya inti ketiga tujuan perusahaan tersebut tidak jauh berbeda. Hanya penekanannya saja yang membedakan tujuan yang ingin dicapai oleh masing-masing perusahaan antara satu dan yang lain.

Indeks IDX30 adalah indeks yang terdiri dari 30 saham yang konstituennya dipilih dari konstituen Indeks LQ45. Konstituen Indeks LQ45 dipilih karena saat ini Indeks LQ45 sudah dapat menggambarkan kinerja saham dengan likuiditas tinggi dan kapitalisasi pasar besar. Hanya saja, beberapa fund manager merasa jumlah 45 saham tersebut terlalu besar. Jumlah konstituen Indeks IDX30 yang terdiri dari 30 saham memiliki keunggulan lebih mudah dilakukan replika sebagai acuan portofolio. Selain itu, menurut teori portofolio, jumlah 30 merupakan jumlah diversifikasi aset yang ideal dalam sebuah portofolio. Dasar pertimbangan pemilihan konstituen Indeks IDX30 adalah faktor kuantitatif yang terkait dengan nilai, frekuensi dan hari transaksi serta kapitalisasi pasar. Fenomena dalam penelitian ini adalah perubahan nilai perusahaan yang bervariasi yang terjadi pada Indeks IDX30 yang terdaftar di Bursa Efek Indonesia (BEI) pada tahun 2014-2018 yang dapat menurunkan kepercayaan investor untuk menanamkan investasinya karena perubahan nilai perusahaan tidak konstan sehingga dapat menurunkan nilai perusahaan. Dalam kondisi tersebut, perusahaan perlu membuat keputusan terkait dengan berbagai kebijakan perusahaan yang dapat mempengaruhi nilai perusahaan.

Beberapa faktor yang dapat mempengaruhi perubahan nilai yaitu leverage, profitabilitas dan kebijakan dividen. Perusahaan akan mengupayakan berbagai cara termasuk mencari sumber dana baik berasal dari internal maupun eksternal untuk dapat membiayai bisnisnya tersebut. Teory trade off menjelaskan bahwa semakin tinggi perusahaan melakukan pendanaan hutang maka semakin besar pula resiko mereka untuk mengalami kesulitan keuangan karena membayar bunga tetap yang terlalu besar bagi para debtholders setiap tahunnya dengan kondisi laba bersih yang belum pasti. Namun Teori MM dengan pajak menjelaskan bahwa tingginya penggunaan hutang akan berpengaruh pada meningkatnya nilai perusahaan karena dapat menghemat pajak (Weston dan Copeland, 1996) dalam (Astuti, 2018). Dalam penelitian ini leverage yang diproksi dengan DER (debt to equity ratio). DER (debt to equity ratio) mencerminkan kemampuan perusahaan untuk membayar atau memenuhi kewajibannya dengan modal sendiri.

Dari sudut pandang investor, laba perusahaan juga merupakan indikator lain yang penting untuk menentukan prospek perusahaan dimasa mendatang. Nilai perusahaan dapat dipengaruhi oleh besar kecilnya profitabilitas yang dihasilkan oleh perusahaan. Rasio profitabilitas dalam penelitian ini diproksikan dengan ROE (return on equity). ROE (return on equity) digunakan untuk mengukur kemampuan perusahaan dalam menghasilkan laba bersih setelah pajak berdasarkan modal sendiri. Semakin tinggi ROE (return on equity) menunjukkan bahwa semakin tinggi tingkat pengembalian terhadap 
investasi yang dilakukan dan semakin rendah ROE (return on equity) suatu perusahaan maka tingkat pengembaliannya akan semakin rendah pula.

Indikator lain yang mempengaruhi nilai perusahaan yaitu kebijakan dividen. Teori dividen residual menyatakan bahwa perusahaan akan menetapkan kebijakan dividen setelah semua investasi yang menguntungkan habis dibiayai, yang artinya bahwa dividen yang dibayarkan merupakan sisa setelah semua investasi yang menguntungkan habis dibiayai. Inti dari teori residual adalah perusahaan akan membagikan dividen setelah semua investasi terpenuhi atau dapat dikatakan jika terdapat pendapatan tersisa maka dividen baru akan dibagikan. Namun berdasarkan teori MM dengan pajak rendahnya dividen yang dibagikan dapat berpengaruh terhadap meningkatnya harga saham, sehingga kebijakan dividen apapun yang diambil perusahaan akan berpengaruh pada nilai perusahaan (Weston dan Copeland, 1996) dalam (Astuti, 2018). Kebijakan dividen pada dasarnya adalah penentuan besarnya porsi keuntungan yang akan diberikan kepada pemegang saham. Kebijakan dividen dalam penelitian ini menggunakan proksi DPR (dividend payout ratio). DPR (dividend payout ratio) merupakan persentase dari pendapatan yang akan dibayarkan kepada pemegang saham sebagai cash dividend.

Dari data yang diperoleh, diketahui rata-rata PBV (price book value), DPR (dividend payout ratio), DER (debt to equity ratio) dan ROE (return on equity) dari tahun 2014-2018 pada Indeks IDX30 yang diambil dari 6 (enam) perusahaan ditunjukkan pada gambar berikut :

Gambar 1.1 Rata-rata Perkembangan Nilai Perusahaan yang diukur dengan PBV (price book value) pada Indeks IDX30 tahun 2014-2018

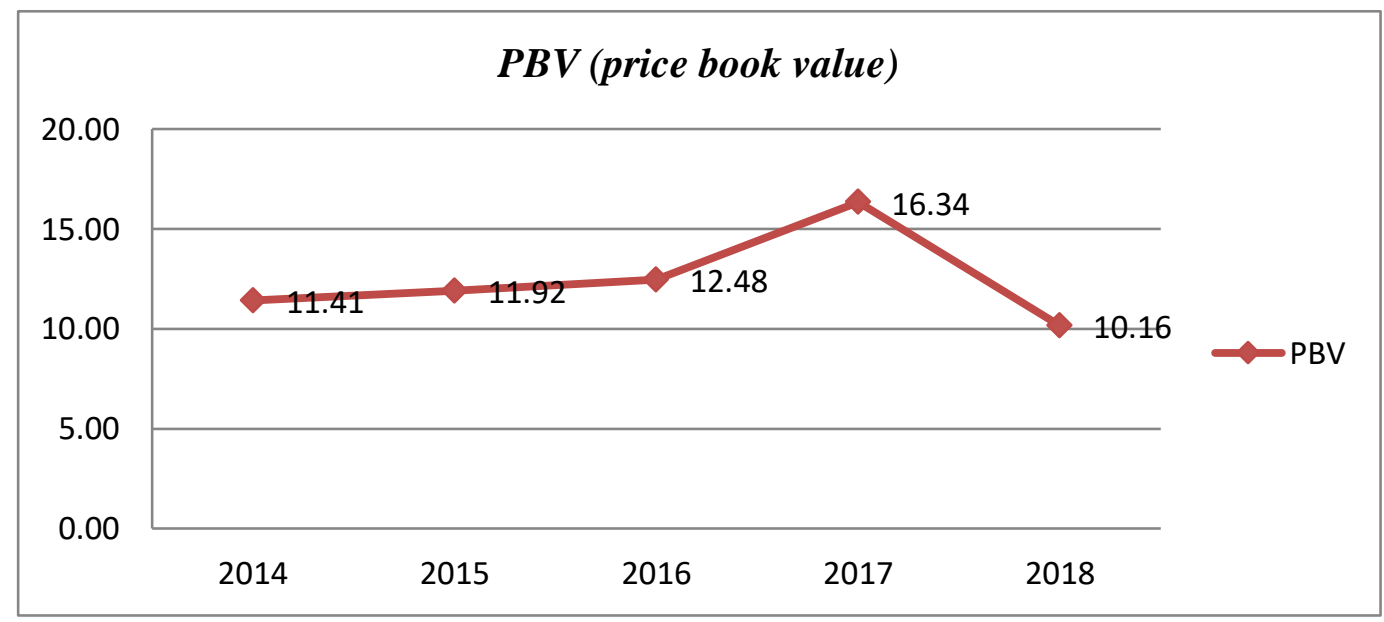

Sumber : Data diolah, 2019

Berdasarkan gambar 1.1, dapat dilihat bahwa nilai perusahaan yang diukur dengan PBV (price book value) selalu mengalami kenaikan dari tahun 2014-2017. Nilai tertinggi berada pada tahun 2017 yaitu sebesar 16,34. Namun pada tahun 2018 PBV (price book value) kembali mengalami penurunan sebesar 10.16. Penurunan PBV (price book value) dari tahun 2017 ke tahun 2018 yaitu sebesar 6,18.

Gambar 1.2 Rata-rata peningkatan dan penurunan kebijakan dividen yang diukur dengan DPR (dividend payout ratio) pada Indeks IDX30 tahun 2014-2018 


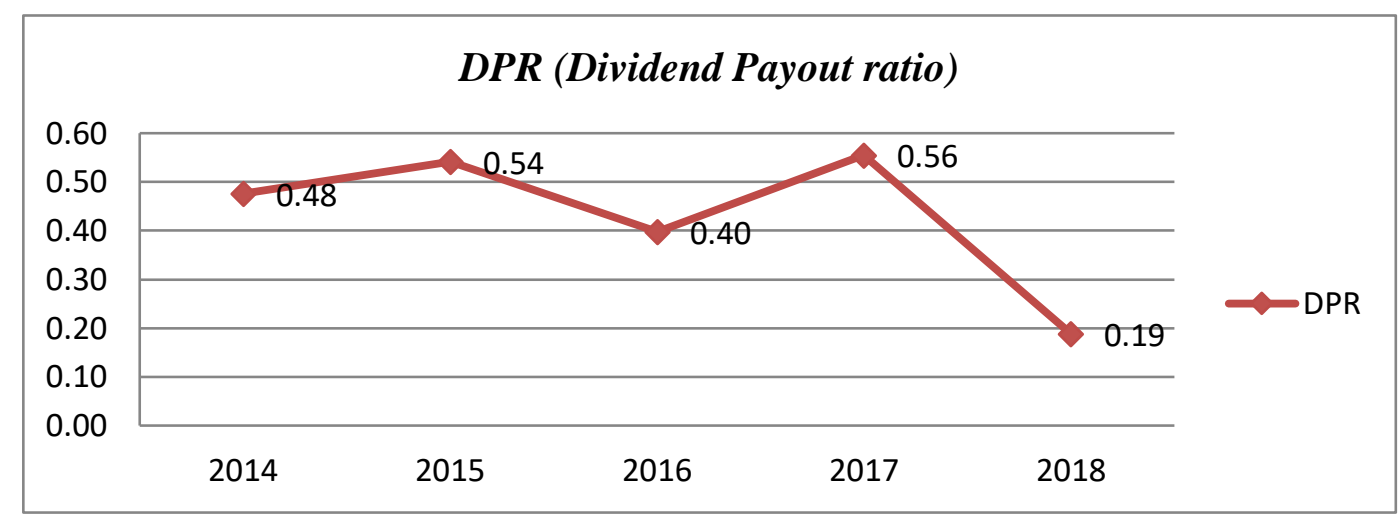

Sumber : Data diolah, 2019

Dari gambar 1.2, dapat dilihat bahwa dari tahun 2014-2018 pada Indeks IDX30 rata-rata DPR mengalami fluktuasi. DPR sempat mengalami peningkatan yang cukup tinggi pada tahun 2017 yaitu sebesar 0.56 tetapi pada tahun 2018 DPR kembali mengalami penurunan yang cukup tajam yaitu sebesar 0.19. Selisih persentase penurunan DPR dari tahun 2017 ke tahun 2018 yaitu sebesar 0.37.

Gambar 1.3 Rata-rata peningkatan dan penurunan leverage yang diukur dengan DER (debt to equity ratio) pada Indeks IDX30 tahun 2014-2018

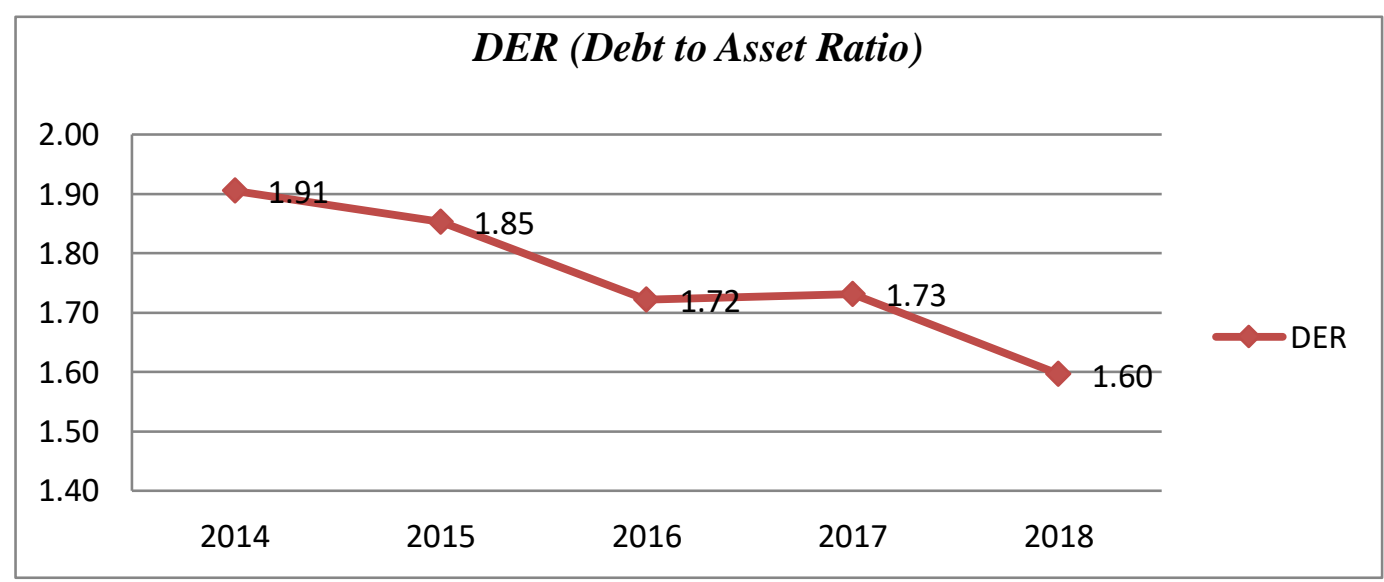

Sumber : Data diolah, 2019

Berdasarkan gambar 1.3, dapat dilihat bahwa DER dari tahun 2014-2018 cenderung mengalami penurunan. Jika dikaitkan dengan teory trade off hal ini dianggap sinyal yang baik. Karena dengan menurunnya hutang akan meningkatkan nilai perusahaan. 
Gambar 1.4 Rata-rata peningkatan dan penurunan profitabilitas yang diukur dengan ROE (return on equity) pada Indeks IDX30 tahun 2014-2018

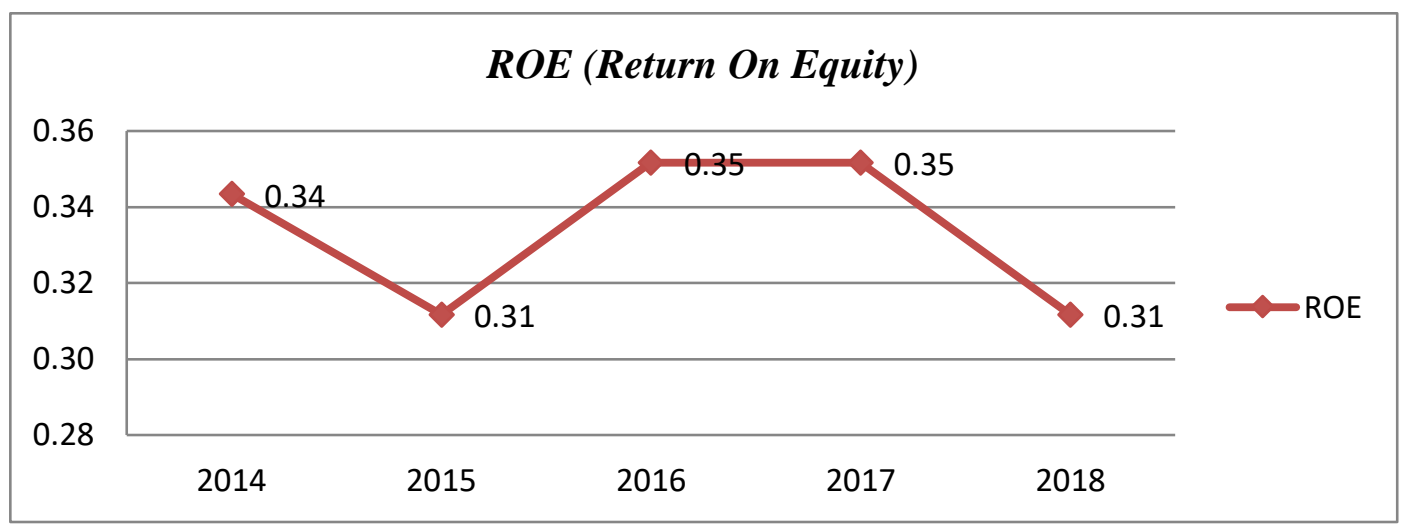

Sumber : Data diolah, 2019

Dari gambar 1.4, dapat dilihat bahwa profitabilitas yang diukur dengan ROE (return on equity) mengalami fluktuasi dari tahun 2014-2018. ROE sempat mengalami peningkatan yang tinggi pada tahun 2016 dan tahun 2017 yaitu sebesar 0.35 tetapi pada tahun 2018 ROE (return on equity) turun sebesar 0.31. Dari 4 (empat) data diatas dapat dilihat bahwa dari tahun 2014, 2015, 2017 dan 2018 setiap DPR (dividend payout ratio) mengalami kenaikan maka PBV (price book value) juga mengalami kenaikan begitupun sebaliknya. Dengan adanya fenomena tersebut peneliti ingin mengetahui seberapa besar kebijakan dividen mempengaruhi nilai perusahaan. Sedangkan DER (debt to equity) dari tahun 2014-2018 cenderung mengalami penurunan, tetapi ROE (return on equity) justru tidak mengalami peningkatan. Jika dilihat dari grafik ROE (return on equity) mengalami fluktuasi yang tidak menentu. Hal ini menimbulkan tanda tanya bagi peneliti sehingga peneliti ingin meneliti lebih dalam lagi.

Beberapa penelitian sebelumnya mengaitkan nilai perusahaan dengan leverage dan profitabilitas yang dimediasi oleh kebijakan dividen. Penelitian yang dilakukan Novitasari (2018) menyatakan bahwa profitabiltas tidak berpengaruh positif signifikan terhadap nilai perusahaan yang dimediasi oleh kebijakan dividen. Sedangkan leverage berpengaruh signifikan positif terhadap nilai perusahaan yang dimediasi oleh kebijakan dividen. Hasil penelitian ini berbeda dengan penelitian yang dilakukan oleh Astuti (2018) dimana hasil penelitian menunjukkan bahwa kebijakan dividen mampu mempengaruhi leverage dan profitabilitas terhadap nilai perusahaan.

Menurut Kasmir (2010) dalam Pematangsiantar (2016), leverage akan menunjukkan besarnya modal sendiri yang dijadikan untuk jaminan hutang. Leverage dalam penelitian ini diukur oleh DER (debt to equity ratio). Semakin besar rasio ini menunjukkan bahwa semakin besar struktur modal yang berasal dari hutang digunakan untuk mendanai ekuitas yang ada. Dimana semakin kecil rasio DER (debt to equity ratio), semakin baik kemampuan perusahaan untuk dapat bertahan dalam kondisi yang buruk. Rasio DER (debt to equity ratio) yang kecil mampu memenuhi kewajibannya kepada kreditur.

Kebijakan hutang akan memberikan dampak pendisiplinan manajer untuk mengoptimalkan penggunaan dana yang ada karena hutang yang cukup besar akan 
menimbulkan kesulitan keuangan dan atau resiko kebangkrutan sehingga berpengaruh terhadap nilai perusahaan tersebut di mata para investor. Dimana dapat dikatakan bahwa semakin kecil rasio hutang (leverage) perusahaan, maka kemampuan perusahaan untuk membayar dividen juga akan tinggi dan nilai perusahaan akan tercermin dalam harga saham perusahaan akan semakin meningkat, karena tingkat kepercayaan investor terhadap perusahaan akan makin meningkat.

$\mathrm{H} 1$ : Leverage berpengaruh signifikan terhadap nilai perusahaan

Rasio profitabilitas digunakan untuk mengukur efektivitas manajemen secara keseluruhan yang ditunjukan oleh besar kecilnya tingkat keuntungan yang diperoleh dalam hubungannya dengan penjualan maupun investasi. Menurut Fahmi (2012) dalam Ramadhani dkk (2018), semakin baik rasio profitabilitas maka semakin baik menggambarkan kemampuan tingginya perolehan keuntungan perusahaan. Sementara nilai perusahaan merupakan harga yang bersedia di bayar oleh calon pembeli andai perusahaan tersebut dijual. Tingginya minat investor untuk menanamkan modalnya pada perusahaan dengan rasio profitabilitas yang tinggi, akan meningkatkan harga saham sehingga akan meningkatkan nilai perusahaan, karena dimata investor perusahaan tersebut memiliki prospek masa depan yang sangat baik. Semakin besar profitabilitas yang dimiliki perusahaan, maka semakin meningkat pula nilai perusahaannya. (Ramadhani, 2018).

$\mathrm{H} 2$ : Profitabilitas bepengaruh signifikan terhadap nilai perusahaan.

Arilaha (2009) dalam Astuti (2018) berpendapat bahwa leverage berpengaruh negatif terhadap nilai kebijakan dividen. Hal tersebut mendukung Rozef (1982) dalam Astuti (2018) yang menyebutkan jika perusahaan mempunyai hutang yang tinggi maka perusahaan tersebut akan membagikan dividen yang rendah. Hutang tinggi yang dimiliki perusahaan menyebabkan pihak manjemen memprioritaskan pelunasan kewajiban terlebih dahulu sebelum memutuskan bayar dividen pada investor, karena laba yang dihasilkan perusahaan akan digunakan terlebih dahulu untuk melunasi kewajibannya. Sesuai dengan teori dividen residual yang menjelaskan bahwa perusahaan akan membagikan dividen apabila semua kegiatan investasi dan anggaran modal telah habis dibiayai, dengan kata lain perusahaan hanya akan bagi dividen jika ada pendapatan yang tersisa. Hal tersebut mengindikasikan perusahaan yang mempunyai hutang akan memprioritaskan pelunasan hutangnya terlebih dahulu dan cenderung meminimumkan pembayaran dividen, karena sebagian keuntungan akan dialokasikan untuk membayar hutang yang akibatnya akan mempengaruhi besarnya dividen yang dibayarkan pada investor. Jadi, semakin besar kebutuhan perusahaan maka semakin kecil kemampuan perusahaan dalam membayarkan dividen.

H3: Leverage berpengaruh signifikan terhdap kebijakan dividen

Brigham (2001) dalam Nofrita (2013) menjelaskan bahwa profitabilitas merupakan determinan utama sebagai pertimbangan pembayaran dividen. Semakin tinggi profitabilitas menunjukkan semakin baik manajemen dalam menjalankan operasi perusahaan. Perusahaan yang memiliki profitabilitas yang tinggi biasanya akan membagikan dividen yang tinggi pula. 
H4: Profitabilitas berpengaruh signifikan terhadap kebijakan dividen

Pada umumnya tujuan investor melakukan investasi saham adalah untuk mendapatkan keuntungan yaitu capital gain ataupun dividen. Dalam hal ini pemegang saham berharap untuk mendapatkan dividen dalam jumlah yang besar atau minimal relatif sama setiap tahun. Perusahaan juga menginginkan laba ditahan dalam jumlah relatif besar agar leluasa melakukan reinvestasi. Perusahaan harus dapat mengalokasikan laba bersihnya dengan bijaksana untuk memenuhi dua kepentingan yang berbeda. Pembuatan keputusan yang tepat dalam kebijakan dan pembayaran dividen dapat memaksimalkan nilai perusahaan dan nilai para pemegang saham. (Pematangsiantar, 2016).

Kebijakan dividen dalam penelitian ini dapat dilihat dari nilai DPR (Dividend Payout Ratio) yang merupakan bagian dari laba bersih perusahaan yang dibagikan sebagai dividen. Menurut Gordon dan Linther (1963) dalam Pematangsiantar (2016) berdasarkan Bird In The hand Theory, besarnya dividen yang dibagikan kepada para pemegang saham akan menjadi daya tarik bagi pemegang saham karena sebagian investor cenderung lebih menyukai dividen dibandingkan dengan capital gain karena dividen bersifat lebih pasti. Banyaknya investor yang berinvestasi di perusahaan tersebut dapat menyebabkan meningkatnya harga saham sehingga dengan meningkatnya harga saham akan meningkatkan nilai perusahaan itu sendiri. Jadi kebijakan dividen yang ditetapkan oleh perusahaan dapat mempengaruhi nilai perusahaan.

H5 : Kebijakan dividen berpengaruh signifikan terhadap nilai perusahaan

Teori dividen residual menyatakan bahwa perusahaan memutuskan bagi dividen setelah semua investasi yang menguntungkan habis dibiayai, yang berarti perusahaan akan bagi dividen jika ada pendapatan sisa. Perusahaan dengan hutang yang tinggi akan memprioritaskan penggunaan laba untuk membiayai semua investasi dan anggaran modalnya, sehingga makin besar kebutuhan perusahaan akan berdampak pada dividen yang dibayarkan pada investor. Kebijakan yang diambil dalam menentukan jumlah utang tentu memerlukan pertimbangan yang rumit karena secara langsung akan mempengaruhi tingkat pembayaran dividen terhadap investor. Meningkatnya hutang akan menurunkan hak pemegang saham, karena laba yang digunakan untuk membayar dividen jadi berkurang. Rendahnya pembayaran dividen pada perusahaan yang memiliki hutang membuat investor lebih memilih berinvestasi pada perusahaan yang mampu memberikan dividen yang tinggi. Sesuai teori signaling, pembayaran deviden yang rendah dianggap sebagai prospek yang kurang menguntungkan dimasa depan sehingga menyebabkan turunnya kepercayaan investor untuk menanamkan modalnya pada perusahaan yang akan berpengaruh pada penurunan harga saham. Harga saham yang turun akan mempengaruhi nilai perusahaan. Jadi, tingginya penggunaan hutang akan menurukan pembayaran dividen yang dapat menurunkan kepercayaan investor hingga menyebabkan penurunan harga saham secara langsung akan berpengaruh pada turunnya nilai perusahaan.

H6 : Leverage berpengaruh signifikan terhadap nilai perusahaan melalui kebijakan dividen

Menurut bird in the hand theory bahwa investor lebih suka menerima dividen dibanding capital gain. Keuntungan dalam menerapkan teori ini adalah dengan memberikan 
dividen yang tinggi, maka harga saham perusahaan juga semakin tinggi sehingga dapat mempengaruhi nilai perusahaan. Kemampuan perusahaan dalam menghasilkan laba yang tinggi akan menjadi daya tarik bagi investor untuk melakukan investasi pada perusahaan tersebut. Hal ini mensinyalkan jika perusahaan mampu menghasilkan laba yang tinggi, maka akan berpengaruh terhadap tingginya nilai perusahaan (Husnan, 2001) dalam (Astuti, 2018). Kemampuan perusahaan dalam menghasilkan laba yang tinggi dari kegiatan usaha hingga mampu mensejahterakan pemegang saham lewat pembagian dividen yang tinggi dinilai memiliki prospek yang baik dimasa mendatang karena pembagian dividen yang tinggi akan mempengaruhi reaksi permintaan harga saham sehingga nilai perusahaan ikut meningkat. (Astuti, 2018).

H7 : Profitabilitas berpengaruh signifikan terhadap nilai perusahaan melalui kebijakan dividen

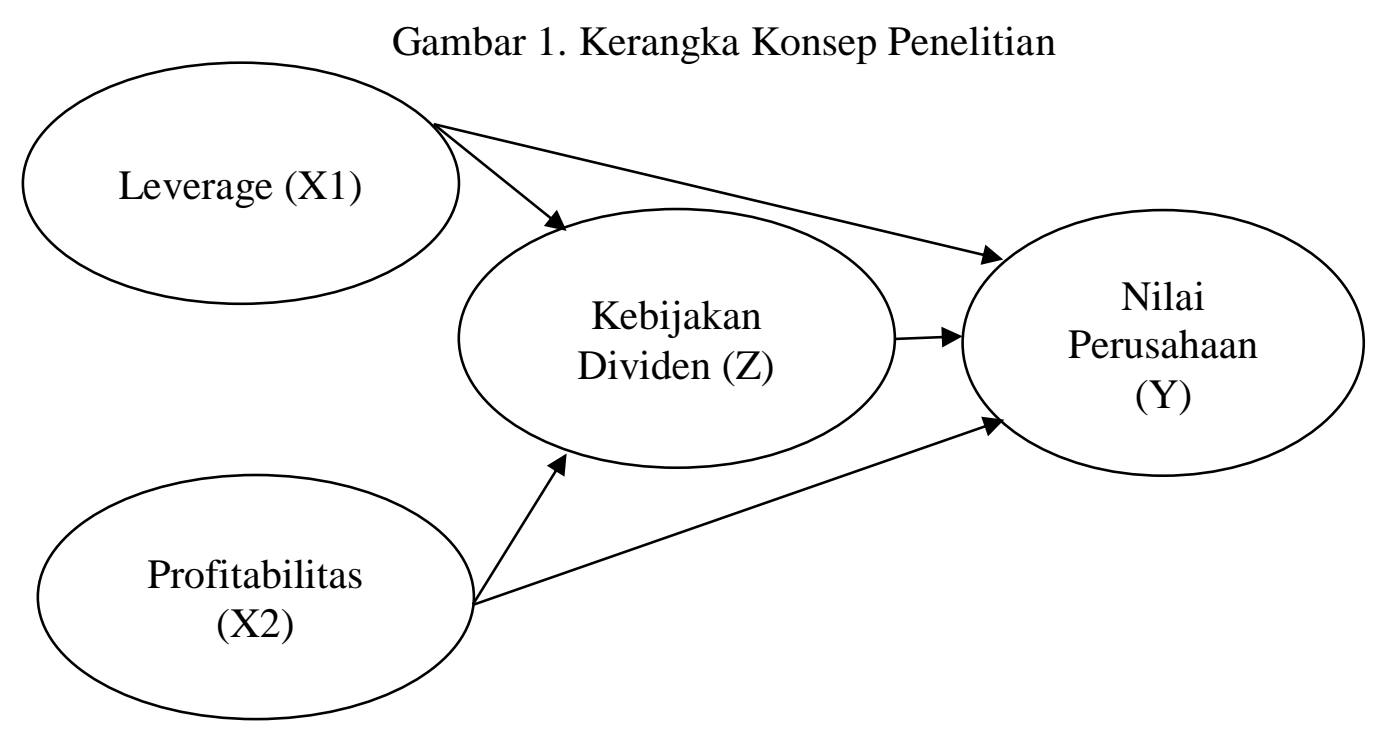

\section{Motodelogi penelitian}

Penelitian ini merupakan penelitian deskripsif-kuantitatif. Sumber data yang digunakan untuk penelitian ini diperoleh dari situs resmi Bursa Efek Indonesia (BEI) yaitu www.idx.ci.id. Sampel dalam penelitian ini berjumlah 6 perusaha di IDX30 yang dipilih dengan purposive sampling.

Variabel dan indikator yang digunakan dalam penelitian ini dapat dilihat dalam tabel berikut : 
Tabel 1. Indentifikasi Variabel

\begin{tabular}{lll}
\hline Variabel & Definisi & Indikator \\
\hline
\end{tabular}

Leverage adalah rasio yang digunakan untuk

Leverage (X1) mengukur kemmapuan perusahaan untuk memenuhi seluruh kewajibannya baik jangka

Debt To Equity Ratio (DER) pendek maupun jangka panjang.

Profitabilitas (X2) Profitabilitas adalah rasio yang digunakan untuk mengukur kemampuan perusahaan

Return On Equity (ROE) menghasilkan keuntungan pada tingkat penjualan, asset dan modal saham tertentu.

Kebijakan Dividen

Kebijakan dividen adalah keputusan perusahaan yang terkait dengan pembiayaan Dividend Payout ratio (DPR) (Z) meliputi pembayaran dividen maupun laba ditahan

Nilai Perusahaan $(\mathrm{Y})$

Nilai perusahaan adalah persepsi investor terhadap perusahaan yang erat kaitannya

Price Book Value (PBV) dengan harga saham.

Sumber : Konsep yang dikembangkan dalam penelitian, 2019

Data dianalisis dengan menggunakan metode Partial Least Square (PLS) dan menggunakan tools SmartPLS. PLS adalah salah satu metode alternatif SEM (structural equation modeling) yang digunakan untuk mengatasi permasalahan dalam hubungan. Jumlah sampel tidak harus banyak dan tidak memerlukan banyak asumsi.

\section{Hasil dan Pembahasan}

\section{Evaluasi Model Pengukuran (outer model)}

Tabel 2.Uji Validitas Konvergen dengan Loading Factor

\begin{tabular}{lccc}
\hline \multicolumn{1}{c}{ Variabel } & Indikator & $\begin{array}{c}\text { Loading } \\
\text { Factor }\end{array}$ & Keterangan \\
\hline Leverage & DER & 1,000 & Valid \\
\hline Profitabilitas & ROE & 1,000 & Valid \\
\hline Kebijakan Dividen & DPR & 1,000 & Valid \\
\hline Nilai Perusahaan & PBV & 1,000 & Valid \\
\hline
\end{tabular}

Sumber : data diolah, 2019

Berdasarkan tabel 3 nilai loading factor yang dihasilkan dapat diketahui semua indikator masing-masing variabel baik leverage, profitabilitas, kebijakan dividend dan nilai perusahaan memiliki nilai loading factor $>0,7$. Dengan demikian indikator terseut dapat dinyatakan sebagai pengukur variabel latennya. 
Tabel 3. Uji Validitas Discriminant dengan Cross Loading dan $\sqrt{ }$ AVE

\begin{tabular}{lccc}
\hline Variabel & Cross Loading & $\sqrt{ }$ AVE & Keterangan \\
\hline Leverage & 1,000 & 1,000 & Valid \\
\hline Profitabilitas & 1,000 & 1,000 & Valid \\
\hline Kebijakan Dividen & 1,000 & 1,000 & Valid \\
\hline Nilai Perusahaan & 1,000 & 1,000 & Valid \\
\hline
\end{tabular}

Sumber : data diolah, 2019

Berdasarkan tabel 4 daapt dilihat bahwa nilai akar AVE yang dihasilkan dapat dketahui bahwa semua indikator masng-masing variabel yaitu leverage, profitabilitas, kebijakan dividend an nilai perusahaan $>0,5$. Dengan demikian indikator tersebut dapat dinyatakan valid sebagai pengukur variabel latennya.

Tabel 4. Uji Reliabilitas dengan Composite Reliability dan Cronbach Alpha

\begin{tabular}{lccc}
\hline \multicolumn{1}{c}{ Variabel } & Composite reliability & Cronbach alpha & Keterangan \\
\hline Leverage & 1,000 & 1,000 & Reliabel \\
\hline Profitabilitas & 1,000 & 1,000 & Reliabel \\
\hline Kebijakan Dividen & 1,000 & 1,000 & Reliabel \\
\hline Nilai Perusahaan & 1,000 & 1,000 & Reliabel \\
\hline
\end{tabular}

Sumber : Data diolah, 2019

Berdasarkan tabel 5 dapat dilihat bahwa nilai composite reliability pada keempat variabel laten berada diatas 0,7 dan hasil evaluasi crobach alpha di atas 0,6. Hal tersebut menunjukkan reliabilitas alat ukur yang tinggi, yakni pengukur dari masing-masing variabel berkorelasi tinggi.

\section{Evaluasi Model Struktural (Inner Model)}

Tabel 5. Hasil Evaluasi Model Struktural dengan R Square

\begin{tabular}{lrc}
\hline & R Square & Adjusted R Square \\
\hline Kebijakan Dividen & 0,427 & 0,384 \\
\hline Nilai Perusahaan & 0,971 & 0,968 \\
\hline
\end{tabular}

Sumber : Data diolah, 2019

Berdasarkan tabel 6 hasil pengujian menunjukkan nilai $\mathrm{R}^{2}$ untuk variabel kebijakan dividen sebesar 0,427 (mediator). Nilai tersebut mengindentifikasikan bahwa variabel kebijakan dividen (Z) dapat dijelaskan oleh variabel leverage (X1) dan profitabilitas (X2) sebesar $42,7 \%$ sedangkan sisanya 57,3\% dipengaruhi oleh variabel lain. Sedangkan hasil $\mathrm{R}^{2}$ untuk variabel nilai perusahaan (Y) sebesar 0,971. Nilai tersebut mengindentifikasikan bahwa variabel nilai perusahaan dapat dijelaskan oleh variabel leverage (X1), profitabilitas (X2) dan kebijakan dividen (Z) sebesar 97,1\% sisanya 2,9\% dipengaruhi oleh variabel lain. 


\section{Gambar 3. Hasil Output PLS Algorith}

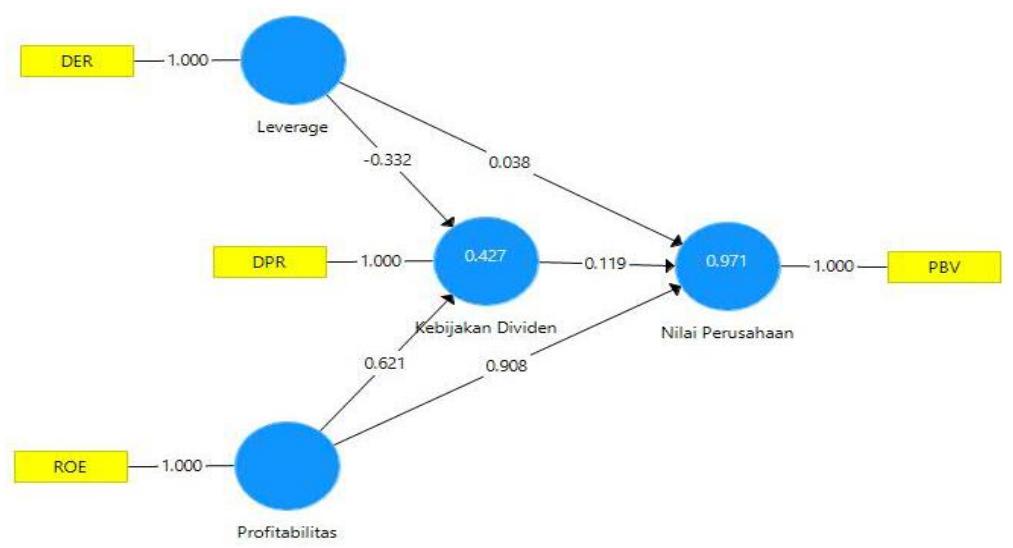

Sumber : Output PLS, 2019

Pada gambar 3 dapat dijelaskan bahwa bentuk bulat dicerminkan sebagai variabel dan bentuk kotak dicerminkan sebagai indikator. Pada penelitian ini, masing-masing variabel sama dengan indikatornya. Seperti variabel leverage dengan indikatornya DER, diikuti dengan, profitabilitas, kebijakan dividen, dan nilai perusahaan. Kemudian juga dijelaskan antar hubungan langsung dan tidak langsung. Hubungan langsungnya adalah leverage dengan nilai perusahaan, profitablitas dengan nilai perusahaan, leverage dengan kebijakan dividen, profitabilitas dengan kebijakan dividen dan kebijakan dividen dengan nilai perusahaan. Sedangkan hubungan tidak langsungnya adalah kebijakan dividen memediasi/tidak memediasi leverage dengan nilai perusahaan dan kebijakan dividen rupiah memediasi/tidak memediasi profitabilitas terhadap nilai perusahaan.

Tabel 6

Path Coefficient (Mean, STDEV, T-Value, P-Values)

\begin{tabular}{lccccc}
\hline & $\begin{array}{c}\text { Original } \\
\text { Sample (O) }\end{array}$ & $\begin{array}{c}\text { Sample } \\
\text { Mean (M) }\end{array}$ & $\begin{array}{c}\text { Standard } \\
\text { Deviation } \\
\text { (STDEV) }\end{array}$ & $\begin{array}{c}\text { T Statistick } \\
(\mid \text { O/STDEV|) }\end{array}$ & $\begin{array}{c}\text { P } \\
\text { Value }\end{array}$ \\
\hline $\begin{array}{l}\text { Leverage -> Nilai } \\
\text { Perusahaan }\end{array}$ & 0,038 & 0,029 & 0,032 & 1,165 & 0,245 \\
\hline $\begin{array}{l}\text { Profitabilitas -> Nilai } \\
\text { Perusahaan }\end{array}$ & 0,908 & 0,925 & 0,045 & 20,126 & 0,000 \\
\hline $\begin{array}{l}\text { Leverage -> Kebijakan } \\
\text { Dividen }\end{array}$ & $-0,332$ & $-0,341$ & 0,141 & 2,349 & 0,019 \\
\hline $\begin{array}{l}\text { Profitabilitas -> Kebijakan } \\
\text { Dividen }\end{array}$ & 0,621 & 0,603 & 0,188 & 3,302 & 0,001 \\
\hline $\begin{array}{l}\text { Kebijakan Dividen -> Nilai } \\
\text { Perusahaan }\end{array}$ & 0,119 & 0,100 & 0,055 & 2,169 & 0,031 \\
\hline \begin{tabular}{l} 
Sumber : Output PLS, \\
\hline
\end{tabular}
\end{tabular}

Sumber : Output PLS, 2019 
Tabel 7. Specific Indirect Effects (Mean, STDEV, T-Value, P-Values)

\begin{tabular}{|c|c|c|c|c|c|}
\hline & $\begin{array}{c}\text { Original } \\
\text { Sample } \\
(\mathrm{O})\end{array}$ & $\begin{array}{c}\text { Sample } \\
\text { Mean } \\
\text { (M) }\end{array}$ & $\begin{array}{c}\text { Standard } \\
\text { Deviation } \\
\text { (STDEV) }\end{array}$ & $\begin{array}{c}\text { T Statistik } \\
(\mid \mathrm{O} / \text { STDEV } \mid)\end{array}$ & $\begin{array}{c}\mathrm{P} \\
\text { Value }\end{array}$ \\
\hline $\begin{array}{l}\text { Leverage -> Kebijakan } \\
\text { Dividen -> Nilai Perusahaan }\end{array}$ & $-0,039$ & $-0,033$ & 0,024 & 1,666 & 0,096 \\
\hline $\begin{array}{l}\text { Profitabilitas -> Kebijakan } \\
\text { Dividen -> Nilai Perusahaan }\end{array}$ & 0,074 & 0,060 & 0,036 & 2,045 & 0,041 \\
\hline
\end{tabular}

Sumber : Output PLS, 2019

Tabel 8. Total Effects (Mean, STDEV, T-Value, P-Values)

\begin{tabular}{lccccc}
\hline & $\begin{array}{c}\text { Original } \\
\text { Sample } \\
(\mathrm{O})\end{array}$ & $\begin{array}{c}\text { Sample } \\
\text { Mean } \\
(\mathrm{M})\end{array}$ & $\begin{array}{c}\text { Standard } \\
\text { Deviation } \\
(\mathrm{STDEV})\end{array}$ & $\begin{array}{c}\text { T Statistick } \\
(|\mathrm{O} / \mathrm{STDEV}|)\end{array}$ & $\begin{array}{c}\mathrm{P} \\
\text { Value }\end{array}$ \\
\hline Leverage $>$ Nilai Perusahaan & $-0,001$ & $-0,004$ & 0,022 & 0,083 & 0,934 \\
\hline $\begin{array}{l}\text { Profitabilitas -> Nilai } \\
\text { Perusahaan }\end{array}$ & 0,982 & 0,985 & 0,020 & 48,034 & 0,000 \\
\hline $\begin{array}{l}\text { Leverage -> Kebijakan Dividen } \\
\begin{array}{l}\text { Profitabilitas -> Kebijakan } \\
\text { Dividen }\end{array}\end{array}$ & $-0,332$ & $-0,341$ & 0,141 & 2,349 & 0,019 \\
\hline $\begin{array}{l}\text { Kebijakan Dividen -> Nilai } \\
\text { Perusahaan }\end{array}$ & 0,621 & 0,603 & 0,188 & 3,302 & 0,001 \\
\hline
\end{tabular}

Sumber : Output PLS, 2019

Hasil pengujian pada Tabel 7 digunakan untuk menguji hipotesis yang ada. Hipotesis pertama menyatakan bahwa leverage berpengaruh signifikan terhadap nilai perusahaan. hasil pengujian menunjukkan variabel leverage memiliki T-statistik sebesar 1,165 dan $p$ value sebesar 0,245, sedangkan t-tabel ssebesar 2,055 dan p-value $<0,05$ tau 5\%. Hasil pengujian menunjukkan bahwa T-statistik $1,165<2,055$ dan $p$-value 0,245 $>0,05$. Hal tersebut menunjukkan bahwa variabel leverage secara langsung tidak berpengaruh signifikan positif terhadap nilai perusahaan dengan kata lain $\mathrm{H} 1$ ditolak. Hal ini berarti jika leverage mengalami peningkatan maka nilai perusahaan akan tetap konstan.

Hipotesis kedua menyatakan bahwa profitabilitas berpengaruh signifikan terhadap nilai perusahaan. hasil pengujian menunjukan variabel profitabilitas memiliki T-statistik sebesar 20,126 dan $p$-value sebesar 0,000, sedangkan t-tabel 2,055 dan $p$-value $<0,05$ atau 5\%. Hasil pengujian menunjukkan bahwa nilai T-statistik 20,126>2,055 dan $p$-value $0,000<0,05$. Hal tersebut menunjukkan bahwa variabel profitabilitassecara langsung berpengaruh signifikan positif terhadap nilai perusahaan atau dengan kata lain $\mathrm{H} 2$ diterima. Hal ini berarti jika profitabilitas mengalami pengkatan maka nilai perusahaan juga akan meningkat.

Hipotesis ketiga menyatakan bahwa leverage berpengaruh signifikan terhadap kebijakan dividen. Hasil pengujian menunjukkan variabel leverage memiliki T-statistik sebasar 2,349 dan $p$-value 0.019, sedangkan t-tabel sebesar 2,055 dan $p$-value < 0,05 atau $5 \%$. Hasil pengujian menunjukkan bahwa nilai T-statistik 2,349>2,055 dan $p$-value $0,019<0,05$. Hal tersebut menunjukkan bahwa variabel leverage secara langsung berpengaruh signifikan negatif terhadap kebijakan dividen atau dengan kata lain $\mathrm{H} 3$ diterima. Hal ini berarti jika leverage mengalami peningkatan maka akan menurunkan 
kebijakan dividen.

Hipotesis keempat menyatakan bahwa profitabilitas berpengaruh signifikan terhadap kebijakan dividen. Hasil pengujian menunjukkan variabel profitabilitas memiliki T-statistik sebesar 3,302 dan $p$-value sebesar 0,001, sedangkan t-tabel sebesar 2,055 dan $p$-value $<0,05$ atau 5\%. Hasil pengujian menunjukkan bahwa T-statistik 3,302 $>2,055$ dan $p$-value $0,001<0,005$. Hal tersebut menunjukkan bahwa profitabilitas secara langsung berpengaruh signifikan positif terhadap kebijakan dividen atau dengan kata lain H4 dterima. Hal ini berarti jika profitabilitas mengalami peningkatan maka kebijakan dividen juga akan meningkat.

Hipotesis kelima menyatakan bahwa kebijakan dividen berpengaruh signifikan terhadap nilai perusahaan. hasil pengujian menunjukkan variabel kebijakan dividen memiliki T-statistik sebesar 2,169 dan p-value sebsar 0,031, sedangkan t-tabel sebesar 2,055 dan $p$-value $<0,05$ atau 5\%. Hasil pengujian menunjukkan bahwa T-statistik 2,169 $>2,055$ dan $p$-value $0,031<0,05$. Hal tersebut menunjukkan bahwa kebijakan dividen secara langsung berpengaruh signifikan terhadap nilai perusahaan atau dengan kata lain H5 diterima. Hal ini berarti jika kebijakan dividen mengalami peningkatan maka nilai perusahaan juga akan meningkat.

Hipotesis keenam menyatakan bahwa leverage berpengaruh signifikan terhadap nilai perusahaan melalui kebijakan dividen. Hasil pengujian menunjukkan variabel leverage memiliki T-statistik sebesar 1,666 dan $p$-value 0,096, sedangkan t-tabel sebesar 2,055 dan $p$-value $<0,05$ atau 5\%. Hasil pengujian menunjukkan bahwa T-statistik 1,666 $<2,055$ dan $p$-value 0,099 > 0,05. Hal tersebut menunjukkan bahwa variabel leverage secara tidak langsung tidak berpengaruh signifikan negatif terhadap nilai perusahaan atau dengan kata lain H6 ditolek. Hal ini berarti jika leverage mengalami pengkatan yang dimediasi kebijakan dividen maka nilai perusahaan akan tetap konstan.

Hipotesis ketujuh menyatakan bahwa profitabilitas berpengaruh signifikan terhadap nilai perusahaan melalui kebiajakn dividen. Hasil pengujian variabel profitabilitas memiliki T-statistik sebesar 2,045 dan p-value 0,041, sedangkan t-tabel sebesar 2,055 dan p-value < 0,05 atau 5\%. Hasil pengujian menunjukkan bahwa $\mathrm{T}$ statistik 2,045 $<2,055$ dan $p$-value $0,041<0,05$. Hal tersebut menunjukkan bahwa variabel profitabilitas secara tidak langsung tidak berpengaruh signifikan positif terhadap nnilai perusahaan melalui kebiajakn dividen atau dnegan kata lain $\mathrm{H} 7$ ditolak. Hal ini berarti jika profitabilitas mengalami peningkatan melalui kebijakan dividen maka nilai perusahaa akan tetap konstan.

\section{Simpulan}

Berdasarkan hasil penelitian leverage, profitabilitas dan kebijakan dividen terhadap nilai perusahaan paada IDX30 yng terdaftar di Bursa Efek Indonesia tahun 2014-2018 diperoleh hasil : leverage tidak berpengaruh signifikan positif terhadap nilai perusahaan, profitabilitas berpengaruh signifikan positif terhadap nilai perusahaan, leverage berpengaruh signifikan negatif terhadap kebijakan dividen, profitabilitas berpengaruh signifikan positif terhadap kebijakan dividen, kebijakan dividen berpengaruh signifikan positif terhadap nilai perusahaan, leverage tidak berpengaruh signifikan negative terhadap nilai perusahaan melalui kebiajkan dividend an profitabilitas tidak berpengaruh signifikan postif terhadap nilai perusahaan melalui kebijakan dividen. Saran yang dapat diberiakan dengan berdasarkan hasil adalah : bagi perusahaan 
hendaknya meningkatkan profitabilitas dan nilai perusahaan sehingga dapat menarik minat investor untuk berinvestasi pada perusahaan tersebut, bagi investor, dalam memberikan penilaian terhadap suatu perusahaan sebaiknya juga memperhatikan faktor lain yang mempengaruhi nilai perusahaan, seperti ukuran perusahaan, pertumbuhan perusahaan, keunikan perusahaan, nilai aktiva, penghematan pajak, fluktuasi nilai tukar dan keadaan pasar modal. Karena keadaan suatu perusahaan tidak terlepas dari pengaruh lingkungan eksternal dan internal. Disarankan juga melihat kondisi perusahaan sebelum berinvestasi, karena tidak semua perusahaan yang tergabung di Indeks IDX30 dalam segi asset dan kapasitas pasar memiliki kondisi keuangan yang baik dimasa depan. Sehingga dalam melakukan keputusan investasi tidak hanya melihat pada histori harga saham saja, melainkan juga kinerja perusahaan dan bagi penelitian selanjutnya untuk lebih mempertimbangkan dalam pengambilan objek penelitian. Selain itu peneliti selanjutnya juga disarankan untuk meneliti faktor-faktor lain yang memungkinkan dapat mempengaruhi nilai perusahaan seperti pertumbuhan perusahaan, keunikan perusahaan, nilai aktiva, penghematan pajak, fluktuasi nilai tukar dan keadaan pasar modal, karena nilai perusahaan juga dipengaruhi oleh faktor lain seperti faktor internal dan ekternal.

\section{Referensi}

Astuti, W. A (2018). Pengaruh leverage dan profitabilitas terhadap nilai perusahaan dengan kebijakan dividen sebagai variabel intervening. Skripsi. Fakultas Ekonomi dan Bisnis Universitas Muhammadiyah Yogyakarta. Tersedia di http://repository.umy.ac.id/handle/123456789/20062 diakses 26 Februari 2019

Anwar Hidayat (2018) tersedia http://www.statistikian.com/2018/08/pengerian -partialleast-square-pls.html diakses tanggal 10 Juli 2019

Bursa Efek Indonesia (2018) tersedia di https://www.idx.co.id/ diakses 30 Februari 2019.

Bursa Efek Indonesia (2018). Tersedia di https://pusatis.com/investasi-saham/indekskonstituen/idx30/ diakses 30 Februari 2019.

Ghozali I,. \& Hengky L. (2015). Partial least squares konsep, teknik dan aplikasi menggunakan program smartPLS 3.0. Semarang : Undip

Hanafi, M. M., \& Halim, A. (2016). Analisis laporan keuangan. Yogyakarta : UPP TIM YKPN.

Kamaludin,. \& Indriani. R. (2012). Manajemen keuangan. Bandung : CV mandar Maju.

Nichonotes (2018) tersedia di http://nichonotes.blogspot.com/2018/01/pengertian dividen.html? $\mathrm{m}=1$

Nofrita, R. (2013). Pengaruh profitabiitas terhadap nilai perusahaan dengan kebijakan dividen sebagai variabel intervening, tersedia di hlm 1-25. Tersedia di http://ejournal.unp.ac.id/students/index.php/akt/article/view/86 diakses 26 Februari 2019.

Novitasari, R. (2018). Pengaruh profitabilitas dan leverage terhadap nilai perusahaan dengan kebijakan dividen sebagai variabel intervening. Skripsi. Fakultas Ekonomi Universitas Islam Negeri Maulana Malik Ibrahim Malang. Tersedia di https://core.ac.uk/download/pdf/160461724.pdf diakses 26 februari 2019.

Pematangsiantar, S. A. (2016, Juni). Pengaruh leverage dan profitabilitas terhadap nilai perusahaan dengan kebijakan dividen sebagai variabel moderating.hlm, 1-9.

Tersedia di 
http://jurnal.stiesultanagung.ac.id/index.php/S/article/download/186/171 diakses 26 Februari 2019.

Permana, I. S,. \& Sedjati, R. S., \& Hendra R. (2018). Pengaruh profitabilitas, leverage dan kepemilikan manajerial terhadap nilai perusahaan melalui kebijakan dividen, hlm 1-6. Tersedia di http://ejournal.unwaha.ac.id/index.php/snami/article/download/287/243/ diakses 26 Februari 2019

Ramadhani, R., \& Akhmadi \& Kuswanto, M. (2018). Pengaruh leverage dan profitabilitas terhadap nilai perusahaan dengan kebijakan dividen sebagai variabel intervening, hlm 1-23. Tersedia di

https://jurnal.untirta.ac.id/index.php/JRBM/article/download/3831/2791 diakses 26 Februari 2019

Sitepu, N. R., \& Wibisono, C. Handoyo. Pengaruh kebijakan dividen, kebijakan leverage dan profitabilitas terhadap nilai perusahaan, hlm 1-14. Tersedia di http://e-journal.uajy.ac.id/8708/1/JURNALEM19344.pdf diakses 26 Februari 2019.

Sujarweni, V. R . Manajemen keuangan. Yogyakarta: Pustaka Baru Press

Verizon Media (2019) tersedia di https://finance.yahoo.com/currency-converter/ diakses 30 Februari 2019.

Yangs, A. (2011). Pengaruh ukuran perusahaan, leverage ,profitabilitas dan kebijakan dividen terhadap nilai perusahaaan.Skripsi. Fakultas Ekonomi Universitas Diponegoro. Tersedia di

http://eprints.undip.ac.id/29436/1/Skripsi006.pdf diakses 26 Februari 2019. 